\title{
Nutrient cycling in a microflagellate food chain: III. Phosphorus dynamics*
}

\author{
O. Ketil Andersen**, Joel C. Goldman***, David A. Caron \& Mark R. Dennett \\ Woods Hole Oceanographic Institution, Woods Hole, Massachusetts 02543, USA
}

\begin{abstract}
As part of a series of grazing experiments in batch cultures, we found that the phagotrophic microflagellate Paraphysomonas imperforata, while grazing on the diatom Phaeodactylum tricornutum or bacteria, was responsible for the bulk of phosphorus regeneration. Regeneration of soluble reactive phosphorus (SRP) and dissolved organic phosphorus (DOP) was negligible in control cultures of the diatom alone, bacteria alone, or the 2 microbes together. When the microflagellate grazed on prey organisms that had been precultured with excess nutrients or under nitrogen limitation there was considerable regeneration of total dissolved phosphorus (TDP $=$ SRP + DOP). Rates of TDP regeneration were greatest during exponential growth of the microflagellate and then decreased through the transition and stationary phases. Overall, up to $70 \%$ of the phosphorus initially incorporated into prey biomass was regenerated through the stationary phase. Total excretion of DOP was about 15 to $20 \%$ of TDP, although DOP excretion made up a larger fraction of total phosphorus excretion for short periods during the exponential phase of growth. When the prey were phosphoruslimited virtually no TDP was excreted throughout the entire growth cycle of the microflagellate. Our results indicate that Protozoa have higher weight-specific rates of phosphorus excretion than do Metazoa. Although metabolic activity is not the sole indicator of the role Protozoa play in the nutrient regeneration process, our results, together with those from size-fractionation studies on nutrient regeneration, point toward a major role for Protozoa in pelagic waters where they constitute a large fraction of the zooplankton biomass.
\end{abstract}

\section{INTRODUCTION}

Until recently, the role that Protozoa play in recycling nutrients in the marine food chain has been poorly understood. In particular, there has been much controversy over the relative roles of bacteria and Protozoa in this process (Johannes 1965, Barsdate et al. 1974, Fenchel \& Harrison 1976, Ammerman \& Azam 1985). Johannes $(1964,1965)$ was the first to make a strong plea that Protozoa played an important role in recycling nutrients, based on his findings that the bodyequivalent excretion times (BEET) for excretion of phosphorus by some marine ciliates were as low as 14 to $20 \mathrm{~min}$. By comparing these values with those of larger marine animals, he concluded that Protozoa must play an important role in nutrient cycling because their weight-specific regeneration rates and

- Contribution No. 6060 from the Woods Hole Oceanographic Institution

- Current address: Norsk Biotech, A/S, P.O. Box 788, Krossen, N-4301 Sandnes, Norway

... Addressee for correspondence the percentage of ingested nutrients they excreted were larger than those of Metazoa (Johannes 1964). These results were criticized by Barsdate et al. (1974) and Fenchel \& Harrison (1976) on the grounds that bacteria rather than Protozoa were the main regenerators of nutrients and that the prime function of Protozoa was to keep bacteria in a state of 'physiological youth'. Additionally, Taylor \& Lean (1981) argued that phosphorus turnover times for ciliates were significantly greater than those attained by Johannes (1965) and Buechler \& Dillon (1974), and that, in general, the efficiency of nutrient incorporation by Protozoa was greater than that of Metazoa. The recent evidence that bacteria play a key role in recycling phosphorus from dissolved nucleotides (Ammerman \& Azam 1985) has added further uncertainty as to which group of microbes plays the major role in regenerating nutrients.

From recent studies, however, it is now abundantly clear that both ciliates and phagotrophic microflagellates regenerate $\mathrm{NH}_{4}^{+}$in large quantities while grazing (Gast \& Horstmann 1983, Sherr et al. 1983, Anders- 
son et al. 1985, Goldman et al. 1985, Van Wambeke \& Bianchi 1985). In fact, reported weight-specific rates of $\mathrm{NH}_{4}^{+}$regeneration from the few studies on marine microflagellates are considerably higher than those for most macrozooplankton (Goldman et al, 1985). On this basis alone, an important role for marine Protozoa in the nutrient regeneration process would be expected. Additionally, we have evidence that some microflagellates are capable of preying on both bacteria and phytoplankton and regenerating nitrogen from all grazed microbes (Goldman \& Caron 1985). Omnivory may thus be an important feeding strategy of phagotrophic microflagellates and a direct mechanism for recycling nutrients in the 'microbial food loop' characterized by Azam et al. (1983).

Recently, we reported our results on nitrogen and carbon cycling in a series of growth and nutrient regeneration experiments involving the heterotrophic microflagellate Paraphysomonas imperforata grazing on both bacteria and the diatom Phaeodactylum tricornutum (Caron et al. 1985, Goldman et al. 1985). In this study we examine the details of phosphorus cycling in these experiments.

\section{METHODS}

Complete details of the experimental design and protocols are given in Goldman et al. (1985). In summary, the heterotrophic microflagellate Paraphy- somonas imperforata (Lucas), capable of grazing on both bacteria and phytoplankton, was first isolated and made bacteria-free. It was then used in a series of grazing and nutrient regeneration experiments with bacteria or the diatom Phaeodactylum tricornutum, the latter either bacteria-free or with bacteria included. The bacteria were either a mixed natural assemblage or a monoculture of Pseudomonas halodurans.

Three sets of experiments were performed, 1 at $24^{\circ} \mathrm{C}$ (Experiment $\mathrm{A}$ ) and the other 2 at $20^{\circ} \mathrm{C}$ (Experiments $\mathrm{B}$ and C). Cultures of Phaeodactylum tricornutum (either. bacteria-free or with bacteria included) or bacteria alone were first grown to mid- or late-exponential growth phase in medium that contained $\mathrm{NH}_{4}^{+}$and $\mathrm{PO}_{4}^{-3}$ in ratios of $10: 1$ or 50 to $60: 1$ under a light-dark cycle. In this way non-nutrient, nitrogen, or phosphorus limitation was ensured in the prey organisms at the time grazing was initiated. The microflagellate was added at the designated time and grazing was followed in the dark for periods of 6 to $7 \mathrm{~d}$. Cultures were sampled in approximate $6 \mathrm{~h}$ intervals throughout the experiments. Experimental conditions are summarized in Table 1.

Particulate phosphorus (PP) was measured on $25 \mathrm{ml}$ samples retained on acid-washed and precombusted Whatman $(G F / F)$ filters. Both soluble reactive phosphorus (SRP) and total dissolved phosphorus (TDP) were measured on the filtrates. After dry combustion of the PP and TDP samples according to the procedures of

Table 1. Summary of experimental conditions for grazing in the dark by the phagotrophic microflagellate Paraphysomonas imperforata on the marine diatom Phaeodactylum tricornutum and on bacteria

\begin{tabular}{|c|c|c|c|c|c|c|}
\hline $\begin{array}{c}\text { Experi- } \\
\text { ment }\end{array}$ & $\begin{array}{l}\text { Tem- } \\
\text { perature } \\
\left({ }^{\circ} \mathrm{C}\right)\end{array}$ & Microbes involved & $\begin{array}{l}\text { N : P ratio } \\
\text { in medium } \\
\text { (by atoms) }\end{array}$ & $\begin{array}{l}\text { Micro- } \\
\text { flagellate } \\
\mu \pm S E^{\cdot} \\
\left(\mathrm{d}^{-1}\right)\end{array}$ & $\begin{array}{c}\text { Prey cell } \\
\text { quota } \\
\left.\text { (pg P cell }{ }^{-1}\right)\end{array}$ & $\begin{array}{c}\text { Prey alkaline } \\
\text { phosphatase } \\
\text { activity } \\
\mu \mathrm{m} \mathrm{P}^{-1} \mathrm{~h}^{-1}\end{array}$ \\
\hline \multirow[t]{7}{*}{ A } & 24 & Diatom & $10: 1$ & - & 0.31 & $<0.1$ \\
\hline & & Bacteria * & & - & NM & NM \\
\hline & & Bacteria $\cdots$ & & - & NM & NM \\
\hline & & Diatom + bacteria & & - & 0.39 & NM \\
\hline & & Diatom + microflagellate & & $3.48 \pm 0.189$ & 0.41 & NM \\
\hline & & Diatom + bactena $\cdots+$ microflagellate & & $3.41 \pm 0.225$ & 0.38 & NM \\
\hline & & Bacteria $\cdots+$ microflagellate & & $3.50 \pm 0.221$ & 0.006 & $<0.1$ \\
\hline \multirow[t]{3}{*}{ B } & 20 & Diatom + bacteria $\cdots$ & 60.1 & - & 0.26 & 0.1 \\
\hline & & Diatom + microflagellate & & $2.55 \pm 0.199$ & 0.22 & 0.4 \\
\hline & & Diatom + bacteria $\cdots+$ microflagellate & & $2.52 \pm 0.021$ & 0.26 & 0.5 \\
\hline \multirow[t]{3}{*}{$\mathrm{C}$} & 20 & Bacteria $\cdots+$ microflagellate & 50.1 & $2.47 \pm 0.101$ & 0.005 & 28 \\
\hline & & Diatom + microflagellate & 60.1 & $2.10 \pm 0.075$ & 0.07 & 33 \\
\hline & & Diatom + microflagellate & 10.1 & $2.31 \pm 0.077$ & 0.21 & 0.6 \\
\hline \multicolumn{7}{|c|}{ NM: Not measured } \\
\hline \multicolumn{7}{|c|}{ - From Goldman et al. (1985) } \\
\hline \multicolumn{7}{|c|}{ - Mixed bacterial population } \\
\hline \multicolumn{7}{|c|}{.. Pseudomonas halodurans } \\
\hline
\end{tabular}


Solorzano \& Sharp (1980), they were analysed for SRP along with the SRP samples by the method of Murphy \& Riley (1962). Dissolved organic phosphorus was calculated as the difference between TDP and SRP, and total phosphorus $(\Sigma P)$ was the sum of TDP and PP.

Alkaline phosphatase (APase) was determined on the prey cultures before addition of the microflagellate. Samples filtered onto $\mathrm{GF} / \mathrm{F}$ filters were treated with acetone and stored at $-20^{\circ} \mathrm{C}$. The enzyme assay was carried out at $40^{\circ} \mathrm{C}$ in $6 \mathrm{mM}$ p-nitrophenyl phosphate in $0.1 \mathrm{~N}$ Tris/ $\mathrm{HCl}$ buffer at pH 9.7 (Andersen \& Olsen unpubl.). Cell counts were measured as described previously (Goldman et al. 1985).

To facilitate data analyses, growth and grazing curves for the microflagellate were divided by visual inspection into the exponential, transition, early stationary, and late stationary growth intervals, as described in Goldman et al. (1985). Specific growth rates of the microflagellate during exponential growth were determined previously and are summarized in Table 1. Changes in cell number for all microbial populations during the experimental period (with designated growth intervals) are shown in Goldman et al. (1985). Measurements of the average phosphorus ingestion ( $\left.I_{P}\right)$ per microflagellate cell (pg P cell ${ }^{-1} \mathrm{~d}^{-1}$ ), the phosphorus regeneration efficiency $\left(R_{p}\right.$, in $\left.\%\right)$, and the microflagellate phosphorus cell quota $\left(Q_{p_{1}}\right.$ in pg $P$ cell $^{-1}$ ) for each interval were made in an identical manner to those made earlier for nitrogen (Goldman et al. 1985). Phosphorus regeneration efficiencies for the summed periods from exponential through the transition and early stationary intervals also were calculated as before.

\section{RESULTS AND DISCUSSION}

\section{Phosphorus excretion by microflagellates}

Patterns of phosphorus regeneration by the microflagellate Paraphysomonas imperforata generally were similar to those we reported for nitrogen regeneration (Goldman et al. 1985). Results from Experiment B, other than data on microflagellate growth rates and prey phosphorus cell quotas (Table 1), are not reported because they were virtually identical to results from Experiment $C$. In comparing the summary mass balances for phosphorus in the control experiments that involved only the prey organisms (Fig. 1) with those in which the microflagellate was actively grazing (Fig. $2 \& 3$ ), it is evident that phosphorus regeneration, like nitrogen regeneration, occurred only in the presence of the microflagellate. In all experiments we were able to maintain a mass balance for phosphorus at least through the first several days of grazing (i.e. $\Sigma \mathrm{P}$

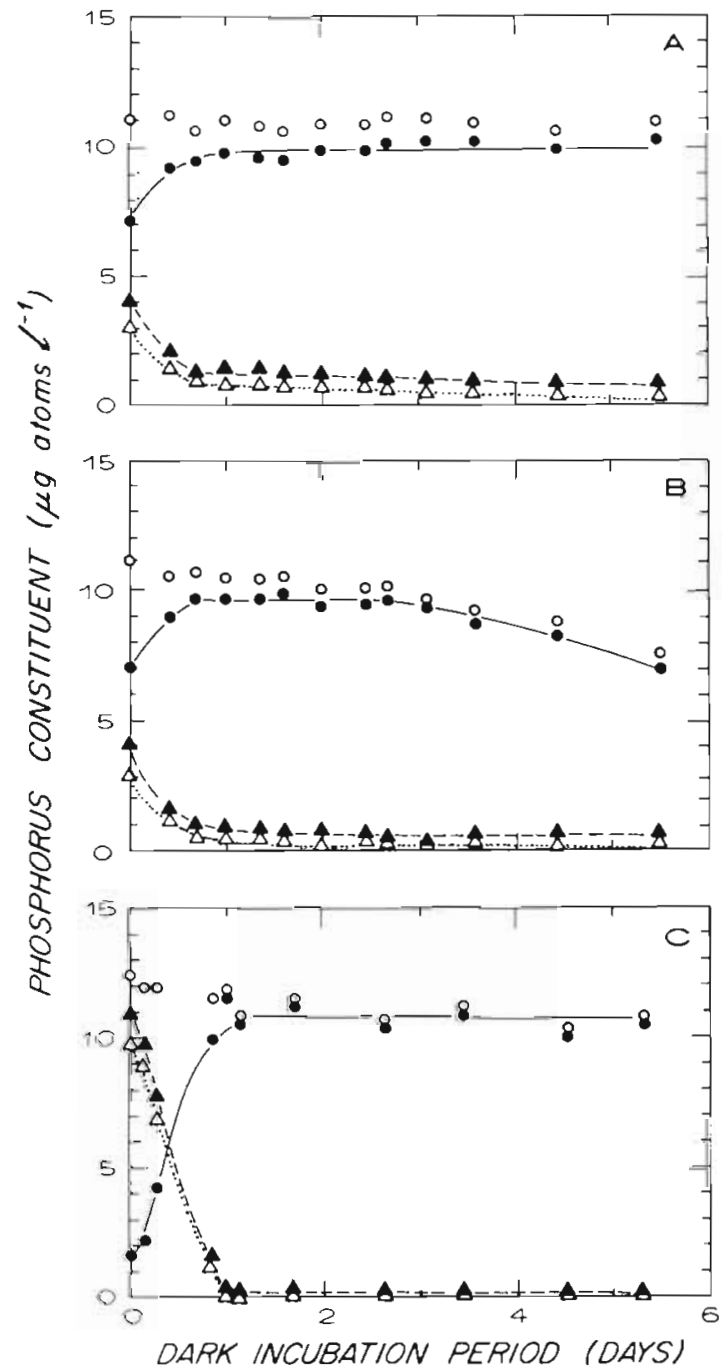

Fig. 1. Dark control experiments without microflagellate present (Experiment A). Phosphorus mass balances are shown: (A) Phaeodactylum tricornutum; (B) Phaeodactylum tricornutum plus mixed bacterial population; (C) mixed bacterial population. $(\Delta)$ Soluble reactive phosphorus; $(\Delta)$ total dissolved phosphorus; ( $)$ particulate phosphorus; (O) total phosphorus (PP + TDP). Corresponding changes in cell numbers and nitrogen constituents are shown in Fig. 1 \& 2 of Goldman et al. (1985)

remained constant). Some reductions in $\Sigma \mathrm{P}$ (as well as total nitrogen), which were coincidental with visible aggregation of particulate material, were observed during the late stationary phase in experiments involving bacteria (Fig. 2B, C). We suspect that these losses were associated with bacterially-mediated wall growth and non-homogeneous sampling (Goldman et al. 1985).

As with nitrogen regeneration, the physiological state of the prey organisms had a major effect on the rates of phosphorus turnover during microflagellate grazing. When prey diatoms or bacteria were grown 


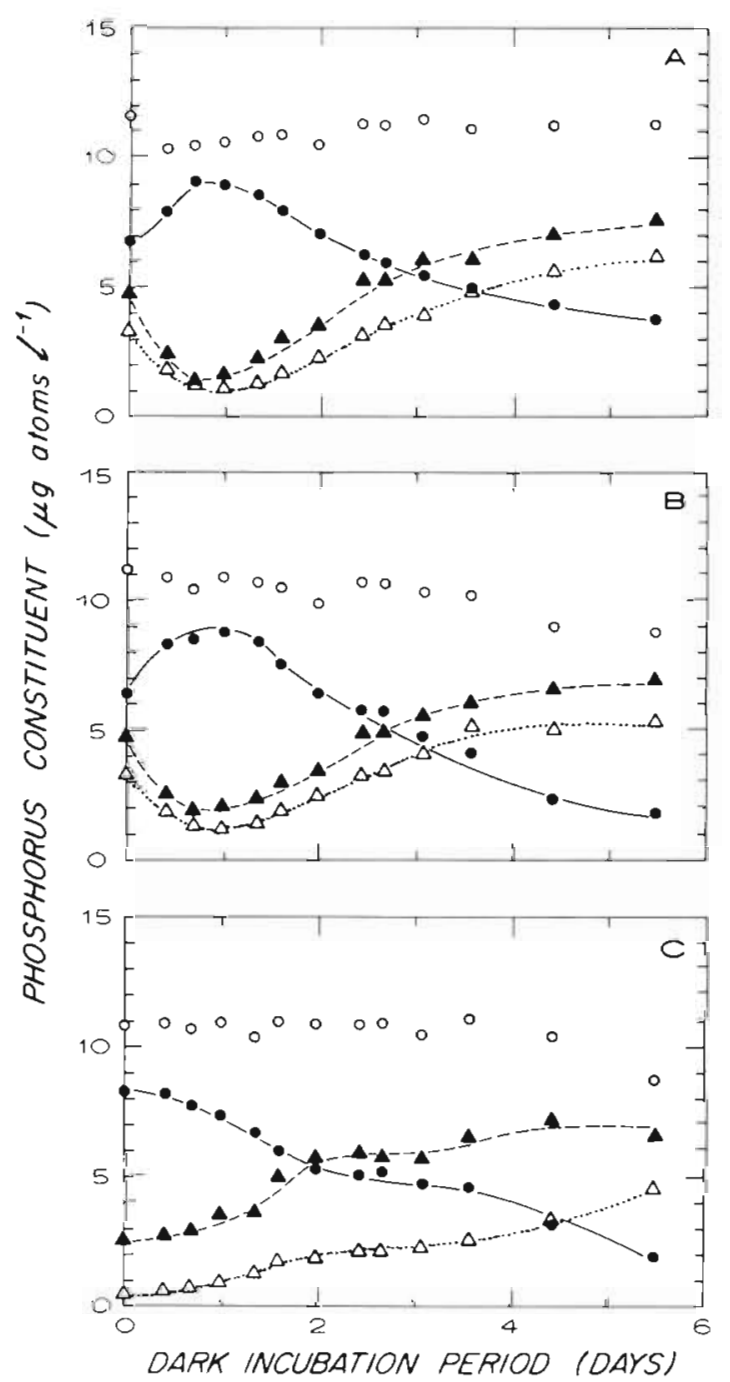

Fig. 2. Grazing in the dark by Paraphysomonas imperforata on non-nutrient-limited microbes (Experiment A). Phosphorus mass balances are shown for Phaeodactylum tricornutum in (A) absence or (B) presence of bacteria, and (C) mixed bacterial population. Symbols same as in Fig. 1. Corresponding changes in cell numbers and nitrogen constituents are shown in Fig. 3 of Goldman et al. (1985)

under either non-nutrient or nitrogen limitation, the highest rates of TDP regeneration $\left(E_{p}\right)$ were found during the exponential and transition growth phases (Fig. 2 \& 3, Table 2). Phosphorus ingestion $\left(I_{P}\right)$ and regeneration rates $\left(E_{P}\right)$ under these conditions were maximal during exponential growth $\left(I_{\mathrm{P}}=10\right.$ to $15 \mathrm{pg} P$ cell ${ }^{-1} \mathrm{~d}^{-1} ; E_{\mathrm{p}}=2$ to $3 \mathrm{pg} P$ cell $^{-1} \mathrm{~d}^{-1} \mathrm{~d}^{-1}$ ). Some of this variation may have been due to the different temperatures in Experiments $\mathrm{A}\left(24^{\circ} \mathrm{C}\right)$ and $\mathrm{C}\left(20^{\circ} \mathrm{C}\right)$. During the transition phase $\mathrm{I}_{\mathrm{P}}$ decreased dramatically to $\leq 2.4 \mathrm{pg} \mathrm{cell} \mathrm{d}^{-1} \mathrm{~d}^{-1}$ and virtually to zero during the stationary phase (Table 2). In contrast, $E_{p}$ decreased more slowly throughout both the transition and station-

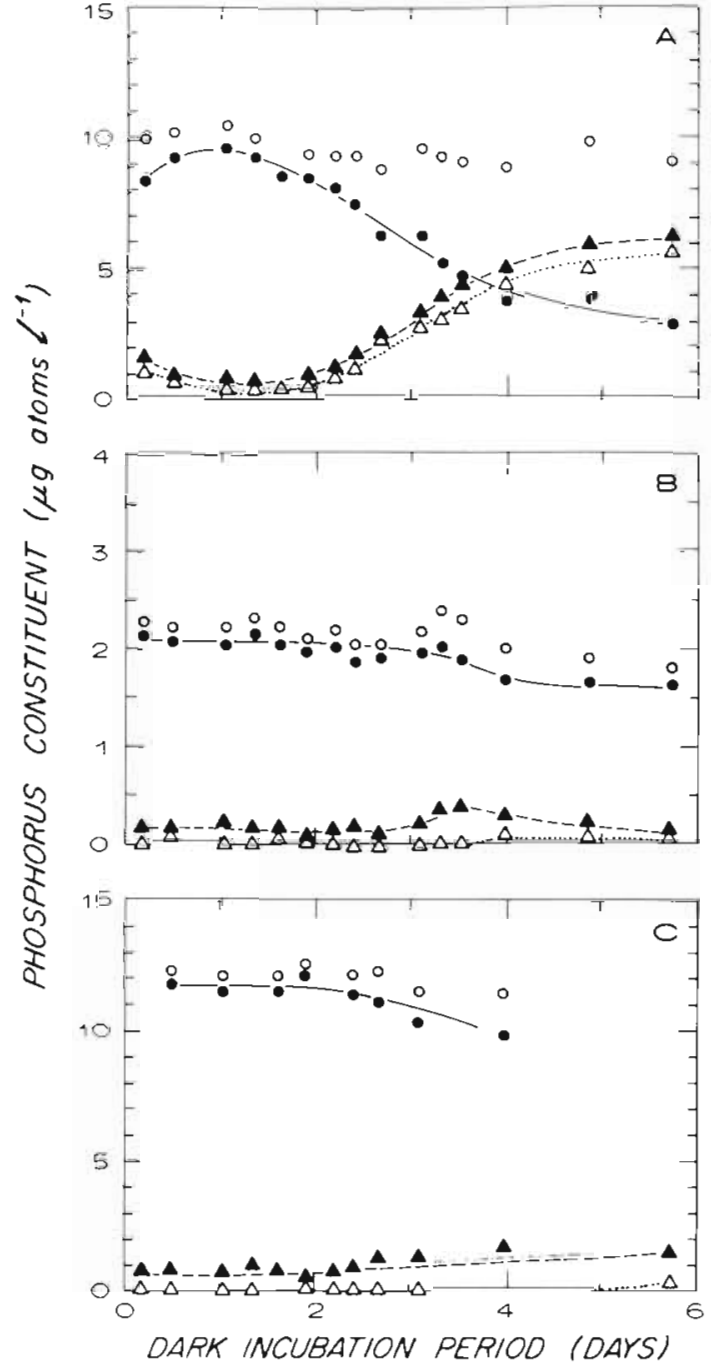

Fig. 3. Grazing in the dark by Paraphysomonas imperforata on nutrient-limited microbes (Experiment C). Phosphorus mass balances are shown for (A) nitrogen-limited Phaeodactylum tricornutum, (B) phosphorus-limited Phaeodactylum tricornutum, (B) phosphorus-limited Phaeodactylum tricornutum, and (C) phosphorus-limited bacteria (Pseudomonas halodurans). Symbols same as in Fig. 1. Corresponding changes in cell number and nitrogen constituents are shown in Fig. 4B, D \& 5 in Goldman et al. (1985)

ary intervals. Thus, measurable phosphorus excretion was detected even when the experiments were ended after 6 to $7 \mathrm{~d}$ incubation (Table 2).

Differences between $E_{P}$ and $I_{p}$ led to an interesting pattern of regeneration efficiencies. As seen in Tables $2 \& 3, R_{p}$ in the nutrient-replete and $\mathrm{N}$-limited cultures increased from 16 to $33 \%$ during the exponential phase, to 23 to $37 \%$ when summed through the transition phase, to 39 to $47 \%$ when the early stationary phase was included. These values were comparable to the nitrogen regeneration efficiencies we measured over the same growth intervals (Goldman et al. 
Table 2. Paraphysomonas imperforata. Phosphorus ingestion $\left(I_{p} ; p g P\right.$ cell $\left.{ }^{-1} d^{-1}\right)$ and regeneration rates $\left(E_{p} ; p g P c e l l^{-1} d^{-1}\right)$ and regeneration efficiency $\left(R_{p} ; \%\right)$ during different phases of grazing when prey microbes were nutrient replete (Experiment $\left.A\right)$ or N-limited (Experiment C)

\begin{tabular}{|c|c|c|c|c|c|c|c|c|c|c|c|c|}
\hline \multirow{2}{*}{$\begin{array}{l}\text { Growth } \\
\text { phase }\end{array}$} & \multicolumn{3}{|c|}{ Diatom } & \multicolumn{3}{|c|}{$\begin{array}{c}\text { Nutrient replete } \\
\text { Diatom + Bacteria }\end{array}$} & \multicolumn{3}{|c|}{ Bacteria } & \multicolumn{3}{|c|}{$\begin{array}{c}\mathrm{N}-\mathrm{lim} \text { it ed } \\
\text { Diatom }\end{array}$} \\
\hline & $I_{P}$ & $E_{p}$ & $R_{P}$ & $\mathrm{I}_{\mathrm{P}}$ & $E_{p}$ & $R_{p}$ & $I_{p}$ & $E_{p}$ & $\mathrm{R}_{\mathrm{p}}$ & $I_{P}$ & $E_{p}$ & $\mathrm{R}_{\mathrm{p}}$ \\
\hline \multicolumn{13}{|l|}{ Interval } \\
\hline Exponential & 14.9 & 2.8 & 19 & 12.4 & 2.6 & 21 & 10.1 & 3.3 & 33 & 12.7 & 2 & 16 \\
\hline Transition & 1.8 & 1.3 & 72 & 1.3 & 1.2 & 92 & 2.4 & 0.7 & 29 & 0.4 & 1.0 & $>100$ \\
\hline Early stationary & 0.1 & 0.9 & $>100$ & 0.1 & 0.5 & $>100$ & 0 & 0.2 & $>100$ & $<0.1$ & 0.8 & $>100$ \\
\hline Late stationary & 0 & 0.3 & $>100$ & 0 & 0.2 & $>100$ & 0 & 0.4 & $>100$ & 0 & 0.4 & $>100$ \\
\hline \multicolumn{13}{|l|}{ Summed through } \\
\hline Transition & & & 23 & & & 25 & & & 37 & & & 28 \\
\hline Early stationary & & & 43 & & & 42 & & & 39 & & & 47 \\
\hline Late stationary & & & 68 & & & 63 & & & 62 & & & 59 \\
\hline
\end{tabular}

1985), indicating a tight coupling between nitrogen and phosphorus regeneration during the early growth phases. However, whereas nitrogen excretion ceased by the end of the transition phase so that nitrogen regeneration efficiency never exceeded about $50 \%$, phosphorus excretion continued throughout the late stationary phase, leading to total phosphorus regeneration efficiencies of 60 to $70 \%$ (Table 2). The higher phosphorus regeneration efficiencies were due to direct release of phosphorus by the microflagellate and not to bacterial mineralization because regeneration efficiency was highest $(68 \%)$ in the culture containing only the diatom and the microflagellate (Table 2). Very little phosphorus was regenerated in the grazed cultures of P-limited bacteria or diatoms throughout the experimental period ( 4 to $8 \%$ ). In contrast, nitrogen regeneration in $\mathrm{N}$-limited cultures was delayed until the stationary phase, but then took place rapidly (Fig. 5D in Goldman et al. 1985). Thus it appears that Paraphysomonas imperforata, when starved, conserves Pcontaining compounds after growth on P-limited prey much more efficiently than it does $N$-limiting compounds after growth on $\mathrm{N}$-limiting prey. As discussed previously, we suspect that conservation of the nutrient in shortest supply by the microflagellate is a common strategy to insure a stoichiometric balance of all nutrients required for biosynthesis of macromolecular components (Goldman et al. 1985). Regulation of phosphorus excretion most likely occurs in a similar fashion.

We were assured of phosphorus limitation in some cultures of Experiment $C$ because APase levels in these cultures were greatly elevated before the microflagellate was added (Table 1). When growing exponentially on P-limited prey, phosphorus ingestion by the microflagellate was only 2.5 to $4 \mathrm{pg} \mathrm{P}$ cell ${ }^{-1} \mathrm{~d}^{-1}$. These low ingestion rates were, in large part, due to the relatively low phosphorus cell quotas of the Plimited prey (Table 1). As reported earlier, microflagellate clearance ( $\mathrm{ml}$ cell ${ }^{-1} \mathrm{~d}^{-1}$ ) and specific growth rates $\left(\mathrm{d}^{-1}\right)$ were not greatly affected by prey nutritional state (Table 1 and Caron et al. 1985). Phosphorus excretion under these conditions did not begin until the transition phase, and then at a very low rate $(0.1$ to $0.2 \mathrm{pg} \mathrm{P}$ cell ${ }^{-1} \mathrm{~d}^{-1}$ ); even lower excretion rates occurred during the stationary period (Table 3). Corresponding regeneration efficiencies never exceeded 4 to $8 \%$. We suspect that the small decrease in $R_{p}$ in the $P$ limited diatom experiment from $8 \%$ during the transition interval to $4 \%$ over the entire experiment (Table 3) was caused by analytical error in distinguishing between very small TDP values over the course of the experiment (Fig. 3B).

The phosphorus cell quota of the microflagellate $\left(Q_{\mathrm{pt}}\right)$ varied both as a function of prey type and prey nutritional state. During exponential growth on diatoms $Q_{p f}$ varied from about $4 \mathrm{pg} \mathrm{P}$ cell $^{-1}$ when the prey were nutrient-replete or $\mathrm{N}$-limited to $1.6 \mathrm{pg} \mathrm{P}$ cell $^{-1}$ when P-limited (Table 4). With bacteria as food

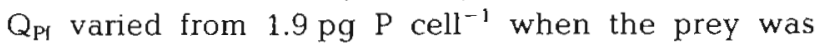
nutrient-replete to $1.6 \mathrm{pg} \mathrm{P}$ cell $^{-1}$ when P-limited. Microflagellate cell size decreased considerably during the stationary phase (Caron et al. 1985), leading to a concomitant 2-fold reduction in $Q_{\mathrm{P} \text { f }}$ regardless of the food quality. Similar reductions in the nitrogen cell quota occurred during the stationary phase (Goldman et al. 1985).

To date, little quantitative data are available on phosphorus excretion rates in Protozoa. Andersson et al. (1985) recently found that inorganic phosphorus and $\mathrm{NH}_{4}^{+}$excretion by a small bacterivorous microflagellate Ochromonas sp. was, respectively, about 30 and $13 \%$ of the original bacterial nutrients ingested. Since the experiments of Andersson et al. (1985) were 
Table 3. Paraphysomonas imperforata. Phosphorus ingestion $\left(I_{p i} p g P c e l l^{-1} d^{-1}\right)$ and regeneration rates $\left(E_{p i} p g P\right.$ cell $\left.{ }^{-1} d^{-1}\right)$ and regeneration efficiency $\left(R_{P} ; \%\right)$ during different phases of grazing when prey microbes were P-limited (Experiment $C$ )

\begin{tabular}{|c|c|c|c|c|c|c|}
\hline \multirow[t]{2}{*}{ Growth phase } & \multicolumn{3}{|c|}{ Bacteria } & \multicolumn{3}{|c|}{ Diatom } \\
\hline & $I_{p}$ & $E_{p}$ & $\mathrm{R} \%$ & $\mathrm{I}_{\mathrm{P}}$ & $E_{p}$ & $\mathrm{R} \%$ \\
\hline \multicolumn{7}{|l|}{ Interval } \\
\hline Exponential & 2.5 & 0 & 0 & 4.0 & 0 & 0 \\
\hline Transition & 1.8 & 0.1 & 6 & 0.5 & 0.2 & 40 \\
\hline Early stationary & 0.1 & 0.1 & 100 & $<0.1$ & 0 & 0 \\
\hline Late stationary & $<0.1$ & $<0.1$ & -50 & 0 & $<0.1$ & $<100$ \\
\hline \multicolumn{7}{|l|}{ Summed through } \\
\hline Transition & & & 4 & & & 8 \\
\hline Early stationary & & & 4 & & & 8 \\
\hline Late stationary & & & 4 & & & 4 \\
\hline
\end{tabular}

relatively short $(50 \mathrm{~h})$ and regeneration efficiencies were based mostly on the exponential growth phase, the differences between the nitrogen and phosphorus excretion efficiencies cannot be attributed to continued phosphorus release late in the exponential phase, as we observed with Paraphysomonas imperforata. Possibly, the bacteria at the start of grazing were moderately $\mathrm{N}$-limited.

Most important, however, the results of Andersson et al. (1985) are in complete agreement with our own findings that nutrient conversion efficiencies are high when microflagellates are growing exponentially. These results should not come as a surprise since it is well established that gross growth efficiencies (based on carbon or energy) of heterotrophic microbes (bacteria and many Protozoa included) can be as high as 50 to $70 \%$ (Calow 1977, Fenchel 1982, Sherr et al. 1983). In fact, in the current experiments the average gross growth efficiency of Paraphysomonas imperforata was $44 \pm 11 \%$, based on cell volume (Caron et al. 1985). Caron et al. (1985) also found that respiration and, to a lesser extent, release of dissolved organic carbon by $P$. imperforata was tightly coupled to nutrient regeneration. Thus, as discussed previously (Goldman \& Caron 1985), the marine microbial food web must be exceedingly complex with, at least, several grazing steps to achieve the high $(90+\%)$ regeneration efficiencies attributed to microzooplankton by Eppley \& Peterson (1979) and Jackson (1979).

\section{Excretion of dissolved organic phosphorus}

The contribution of dissolved organic phosphorus (DOP) to TDP excreted by the microflagellate varied considerably between experiments. By the end of the growth cycle, excreted DOP never exceeded 15 to $20 \%$ of TDP. However, DOP contributed a greater proportion of excreted TDP during earlier growth phases. The most pronounced DOP excretion occurred in Experiment A when the prey were nutrient-replete. Moreover, virtually all of this excretion occurring during the exponential growth phase of the microflagellate, that is, when $I_{p}$ was maximal (Fig. 2). It seems

Table 4. Paraphysomonas imperforata. Phosphorus cell quot a $\left(\mathrm{Q}_{\mathrm{p}}\right.$; pg $\mathrm{P}$ cell $^{-1}$ ) during exponential (and, in parenthesis, stationary) growth and associated BEET value (d) grazing on nutrient-replete (Experiment A) or nutrient-limited microbes (Experiment $\mathrm{C}$ )

\begin{tabular}{|c|c|c|c|}
\hline Experiment & Prey organisms & $\begin{array}{c}\text { Microflagellate } \\
\text { phosphorus cell quota }\end{array}$ & BEET \\
\hline A & $\begin{array}{l}\text { Diatom } \\
\text { Diatom + bacteria } \\
\text { Bacteria }\end{array}$ & $\begin{array}{ll}4.0 & (2.1) \\
3.7 & (1.8) \\
1.9 & (1.6)\end{array}$ & $\begin{array}{l}1.4 \\
1.4 \\
0.6\end{array}$ \\
\hline $\mathrm{C}$ & $\begin{array}{l}\text { P-limited bacteria } \\
\text { P-limited diatom } \\
\text { N-limited diatom }\end{array}$ & $\begin{array}{ll}1.3 & (1.1) \\
1.6 & (1.0) \\
4.0 & (2.3)\end{array}$ & $\begin{array}{l}x \\
x \\
2.0\end{array}$ \\
\hline $\begin{array}{l}\text { - Mixed bacterial } \\
\cdots \text { Pseudomonas hal }\end{array}$ & & & \\
\hline
\end{tabular}


likely that this excreted DOP largely was derived from the release of P-containing compounds during the ejection of food vacuoles by actively feeding microflagellates. Release of DOP during exponential growth varied from 15 to $25 \%$ of TDP excreted when Phaeodactylum tricornutum was the prey to about $70 \%$ of TDP when bacteria were being grazed. It is difficult to speculate, on the basis of our limited data, why DOP excretion of the microflagellate growing exponentially should have been more strongly influenced by the type of prey than by prey physiological state.

Data on dissolved organic phosphorus excretion by grazing marine microplankton are limited and conflicting. Pomeroy et al. (1963), for example, found DOP to account for almost $50 \%$ of TDP excreted by natural zooplankton populations in short ( 2 to $8 \mathrm{~h}$ ) incubations. Taylor \& Lean (1981), in contrast, concluded from their ${ }^{32} \mathrm{P}$ labelling studies that virtually all the phosphorus excreted by a freshwater ciliate and rotifer feeding on phytoplankton was inorganic. Clearly, our own results support the conclusion that DOP excretion in Protozoa can occur, but we suspect that this mode of excretion is highly variable and exceedingly complex. Nonetheless, an important role for DOP in phosphorus cycling recently has been advocated (Jackson \& Williams 1985). The finding of Smith et al. (1985) that DOP production and utilization were in balance and made up a large fraction of phosphorus that was recycled during incubations of microplankton samples from waters off Hawai seems to corroborate this conclusion.

\section{Role of microflagellates in nutrient regeneration}

In trying to reconcile the controversy over whether Protozoa or bacteria are the main regenerators of nutrients in aquatic environments it is important to distinguish between purely detrital systems and those where grazing of living microbes by bacterivorous and herbivorous plankton is the major mechanism controlling the turnover of both heterotrophic and phototrophic biomass. Detrital systems, which involve the breakdown of dead plant and animal organic matter by bacterial mineralization, are characterized by long nutrient turnover times, whereas nutrient turnover in grazing systems is relatively fast. For example, the rate constants for bacterial mineralization of nitrogen and phosphorus from dead phytoplankton to dissolved inorganic forms typically are $<0.1 \mathrm{~d}^{-1}$ for the most labile organic fractions (Harrison 1980). Moreover, bacteria are known to compete efficiently with phytoplankton for phosphorus (Rhee 1972, Faust \& Correll 1976, Harrison et al. 1977, Currie \& Kalff 1984). Decomposition pathways, thus, are probably unimportant for nutrient regeneration in dynamic environ- ments such as pelagic surface waters where there is a reasonable balance between phototrophic and heterotrophic activity and where $90+\%$ of nutrients are believed to be recycled (Eppley \& Peterson 1979) by microplankton $<100 \mu \mathrm{m}$ in size (Harrison 1980) and sometimes < $10 \mu \mathrm{m}$ (Glibert 1983)

The role of bacteria in mineralizing dissolved organic compounds such as amino acids (Hollibaugh 1976) and nucleotides (Ammerman \& Agam 1985) similarly is unclear. Whereas there is compelling evidence that bacterially-mediated turnover of $\mathrm{N}$ and $\mathrm{P}$ in numerous organic compounds is very rapid, the contribution of these compounds relative to inorganic sources arising from protozoan and metazoan excretions is poorly defined.

A key factor in attributing a major role in nutrient regeneration to phagotrophic microflagellates is that these Protozoa have very high weight-specific regeneration rates for both phosphorus and nitrogen. For example, in the current experiments the volume of Paraphysomonas imperforata during exponential growth was $180 \mu^{3}$ when feeding on bacteria and $270 \mu \mathrm{m}^{3}$ when feeding on Phaeodactylum tricornutum (Goldman et al. 1985). Maximum weight-specific rates of phosphorus regeneration of the microflagellate, therefore, ranged from $2.2 \mu \mathrm{g} \mathrm{P}$ mg dry weight ${ }^{-1} \mathrm{~h}^{-1}$ when the diatom was the prey to $3.8 \mu \mathrm{g}_{\text {dry }}$ weight $^{-1}$ $\mathrm{h}^{-1}$ when bacteria were eaten, assuming a specific weight for the microflagellate of $0.2 \mathrm{pg}$ dry weight $\mu^{-3}$ (Sherr et al. 1983). By comparison, the highest observed rates of phosphorus regeneration by marine Metazoa are below $0.5 \mu \mathrm{g} P \mathrm{mg}$ dry weight ${ }^{-1} \mathrm{~h}^{-1}$ (Corner \& Davies 1971, Lehman 1980, Ikeda et al. 1982). Similar differences in weight-specific rates of nitrogen regeneration between Protozoa and Metazoa are evident (Table 3 in Goldman et al. 1985).

Our estimates of BEET ( $\left.Q_{P f} E_{p}^{-1}\right)$ for Paraphysomonas imperforata ranged from 0.6 to $2 \mathrm{~d}$ (Table 4), values which are considerably longer than the tens of minutes found by Johannes (1965) for several Protozoa excreting phosphorus. Taylor \& Lean (1981) similarly found that phosphorus turnover times for a ciliate and a rotifer were on the order of tens of hours. These authors criticized the conclusion of Johannes (1965) that Protozoa regenerate a larger proportion of their ingested nutrients than do Metazoa. They pointed out that, even though Protozoa have greater weight-specific metabolic rates than do Metazoa, they also have extremely high gross growth efficiencies: in effect, Protozoa retain a large fraction of the nutrients they incorporate. Taylor \& Lean (1981) thus concluded that Protozoa are not necessarily responsible for the bulk of nutrient regeneration in aquatic environments.

While we agree, in principal, that metabolic activity is not the sole indicator of nutrient regeneration poten- 
tial, there is compelling evidence that, at least, in pelagic waters Protozoa play a major role in grazing small microbes and in recycling nutrients. For example, from the few size-fractionation studies carried out in oceanic waters we know that microzooplankton account for a large percentage of phosphorus (Harrison 1980, Herbland 1984) and nitrogen regeneration (Glibert 1982). Jackson (1979), by comparing the biomasses of different zooplankton groups, similarly has shown that microzooplankton account for the bulk of water cleared by grazers in an oligotrophic water body such as the North Pacific Gyre. These results, coupled with our own finding that weight-specific nutrient regeneration rates of Protozoa are high, even though nutrient regeneration efficiencies in the microbial food chain are low $(<50 \%)$, makes for a plausible case that ciliates and heterotrophic microflagellates grazing on both bacteria and small phytoplankton are responsible for much of the regeneration in such waters. In productive near-shore waters, where macrozooplankton make up a large fraction of the grazer biomass, the role of Protozoa in nutrient regeneration undoubtedly is reduced (Joint \& Williams 1985).

Acknowledgements. This study was supported by Grant No. OCE-838578 from the National Science Foundation (JCG) and by a Postdoctoral Fellowship from the Norwegian Research Council (OKA).

\section{LITERATURE CITED}

Ammerman, J. W., Azam, F. (1985). Bacterial 5'-nucleotidase in aquatic ecosystems: a novel mechanism of phosphorus regeneration. Science 227: 1338-1340

Andersson, A., Lee, C., Azam, F., Hagström, A. (1985) Release of amino acids and inorganic nutrients by heterotrophic marine microflagellates. Mar. Ecol. Prog. Ser 23 99-106

Azam, F., Fenchel, T., Field, J. G., Meyer-Reil, L. A., Thingstad, F. (1983). The ecological role of water-column microbes in the sea. Mar. Ecol. Prog. Ser. 10: 257-263

Barsdate, R. J., Prentki, R. T., Fenchel, T. (1974). Phosphorus cycle of model ecosystems: significance for decomposer food chains and effect of bacterial grazers. Oikos 25: 239-251

Buechler, D. G., Dillon, R. D. (1974). Phosphorus regeneration in fresh-water paramecia. J. Protozool. 32: 339-343

Calow, P. (1977). Conversion efficiencies in heterotrophic organisms. Biol. Rev. 52: 385-409

Caron, D. A., Goldman, J. C., Andersen, O. K., Dennett, M. R. (1985). Nutrient cycling in a microflagellate food chain: II. Population dynamics and carbon cycling. Mar. Ecol. Prog. Ser. 24: 243-254

Corner, E. D. S., Davies, A. G. (1971). Plankton as a factor in the nitrogen and phosphorus cycles. Adv. mar. Biol. 9: 101-204

Currie, D. J., Kalff, J. (1984). The relative importance of phytoplankton and bacterioplankton to acquire and retain phosphorus. Limnol. Oceanogr. 29: 311-321

Eppley, R. W., Peterson, B. J. (1979). Particulate organic matter flux and planktonic new production in the deep ocean. Nature, Lond. 282: 677-680

Faust, M. A., Correll, D. L. (1976). Comparison of bacterial and algal utilization of orthophosphate in an estuarine environment. Mar. Biol. 34: 151-162

Fenchel, T. (1982). Ecology of heterotrophic microflagellates. II. Bioenergetics and growth. Mar. Ecol. Prog. Ser 8: 225-231

Fenchel, T., Harrison, P. (1976). The significance of bacterial grazing and mineral cycling for the decomposition of particulate detritus. In: Anderson, J. M., Macfadyen, A. (ed.) The role of terrestrial and aquatic organisms in decomposition processes. Blackwell Scientific Publications, Oxford, p. 285-299

Gast, V., Horstmann, U. (1983). N-remineralization of phytoand bacterioplankton by the marine ciliate Euplotes vannus. Mar. Ecol. Prog. Ser. 13: 55-60

Glibert, P. M. (1982). Regional studies of daily, seasonal, and size fraction variability in ammonium remineralization. Mar. Biol. 70: 209-222

Goldman, J. C., Caron, D. A. (1985). Experimental studies on an omnivorous microflagellate: Implications for grazing and nutrient regeneration in the marine microbial food chain. Deep Sea Res. 32; 899-915

Goldman, J. C., Caron, D. A., Andersen, O. K., Dennett, M. R. (1985). Nutrient cycling in a microflagellate food chain: I. Nitrogen dynamics. Mar. Ecol. Prog. Ser. 24: 231-242

Harrison, W. G. (1980). Nutrient regeneration and primary production in the sea. In: Falkowski, P. G. (ed.) Primary productivity in the sea. Plenum Press, New York, p. $433-460$

Harrison, W. G., Azam, F., Renger, E. H., Eppley, R. W. (1977). Some experiments on phosphate assimilation by coastal marine phytoplankton. Mar Biol. 40:9-18

Herbland, A. (1984). Phosphate uptake in the euphotic layer of the Equatorial Atlantic Ocean. Methodological observations and ecological significance. Oceanogr. Trop. 19: $25-40$

Hollibaugh, J. T. (1976). The biological degradation of arginine and glutamic acid in seawater in relation to the growth of phytoplankton. Mar. Biol. 36: 303-312

Ikeda, T., Hing Fay, E., Hutchinson, S. A., Boto, G. M. (1982). Ammonia and inorganic phosphate excretion by zooplankton from inshore waters of the Great Barrier Reef, Queensland. I. Relationship between excretion rates and body size. Aust. J. mar. Freshwat. Res. 33: 5570

Jackson, G. A. (1979). Phytoplankton growth and zooplankton grazing in oligotrophic oceans. Nature, Lond. 284 $439-441$

Jackson, G. A., Williams, P. M. (1985). Importance of dissolved organic nitrogen and phosphorus to biological nutrient cycling. Deep Sea Res. 32: 223-235

Johannes, R. E. (1964). Phosphorus excretion and body size in marine animals: microzooplankton and nutrient regeneration. Science 146: 923-924

Johannes, R. E. (1965). Influence of marine protozoa on nutrent regeneration. Limnol Oceanogr. 10: 434-442

Joint, I. R., Williams, R. (1985). Demands of the herbivore community on phytoplankton production in the Celtic Sea in August. Mar. Biol. 87: 297-306

Lehman, J. T (1980). Nutrient recycling as an interface between algae and grazers in freshwater communities. In: W. C. Kerfoot (ed.) Evolution and ecology of zooplankton communities. University Press of New England, Hanover, p. 251-263

Murphy, J., Riley, J. P. (1962). Determination of phosphate in natural waters. Analytica chim. Acta 27 31-36 
Pomeroy, L. R., Mathews, H. M., Min, H. S. (1963). Excretion of phosphate and soluble compounds by zooplankton Limnol. Oceanogr. 8: 50-55

Rhee, G. Y. (1972). Competition between an alga and an aquatic bacterium for phosphate. Limnol. Oceanogr. 17: 505-514

Sherr, B. F., Sherr, E. B., Berman, T. (1983). Grazing, growth, and ammonium excretion rates of a heterotrophic microflagellate fed with four species of bacteria. Appl. environ. Microbiol. 45: 1196-1201

Smith, R. E. H., Harrison, W. G., Harris, L. (1985). Phosphorus exchange in marine microplankton communities near Hawaii. Mar. Biol. 86: 75-84
Solorzano, L., Sharp, J. H. (1980). Determination of total dissolved phosphorus and particulate phosphorus in natural waters. Limnol. Oceanogr. 25: $754-758$

Taylor, W. D., Lean, D. R. S. (1981). Radiotracer experiments on phosphorus uptake and release by limnetic microzooplankton. Can. J. Fish. Aquat. Sci. 38: 1316-1321

Van Wambeke, F., Bianchi, M. A. (1985). Bacterial biomass production and ammonium regeneration in Mediterranean sea water supplemented with amino acids. 2. Nitrogen flux through heterotrohpic microplankton food chain. Mar. Ecol. Prog. Ser. 23: 117-128

This article was submitted to the editor; it was accepted for printing on March 7, 1986 